Florida International University FIU Digital Commons

FIU Electronic Theses and Dissertations

University Graduate School

$2-27-1997$

\title{
Serum transthyretin in hemodialysis patients : relationship to nutritional status
}

Annmarie Duggan

Florida International University

DOI: $10.25148 /$ etd.FI15101237

Follow this and additional works at: https://digitalcommons.fiu.edu/etd

Part of the Dietetics and Clinical Nutrition Commons

\section{Recommended Citation}

Duggan, Annmarie, "Serum transthyretin in hemodialysis patients : relationship to nutritional status" (1997). FIU Electronic Theses and Dissertations. 3094.

https://digitalcommons.fiu.edu/etd/3094

This work is brought to you for free and open access by the University Graduate School at FIU Digital Commons. It has been accepted for inclusion in FIU Electronic Theses and Dissertations by an authorized administrator of FIU Digital Commons. For more information, please contact dcc@fiu.edu. 


\title{
FLORIDA INTERNATIONAL UNIVERSITY
}

\author{
Miami, Florida
}

SERUM TRANSTHYRETIN IN HEMODIALYSIS PATIENTS:

RELATIONSHIP TO NUTRITIONAL STATUS

\author{
A thesis submitted in partial satisfaction of the \\ requirements for the degree of \\ MASTER OF SCIENCE \\ IN \\ DIETETICS AND NUTRITION \\ by
}

Annmarie Duggan 
TO: Acting Dean Judith A. Blucker College of Health

This thesis proposal, written by Annmarie Duggan, and entitled SERUM TRANSTHYRETIN IN HEMODIALYSIS PATIENTS: RELATIONSHIP TO NUTRITIONAL STATUS, having been approved in respect to style and intellectual content, is referred to you for judgment.

We have read this thesis and recommend that it be approved.

Susan Himburg

Evelyn Enrione

Fatma G. Huffman

Major Professor

Date of Defense: $2 / 27 / 97$

The thesis of Annmarie Duggan is approved.

Acting Dean Judith A. Blucker

College of Health

Richard L. Campbell

Dean of Graduate Studies

Florida International University, 1997 


\section{ACKNOWLEDGEMENTS}

I wish to thank the members of my committee for their helpful comments and patience. I would also like to thank the nurses and dialysis technicians at Complete Dialysis Care, Inc. for their help in obtaining timely and accurate laboratory specimens; Dr. Paulette Johnson for her statistical assistance; REN Laboratories for their support of this project; and especially the hemodialysis patients at Complete Dialysis Care, Inc. for agreeing to participate in this study.

A special thanks must go to my major professor, Dr. Fatma G. Huffman, for her support, guidance and patience throughout the course of this research project. 


\title{
ABSTRACT OF THE THESIS
}

\section{SERUM TRANSTHYRETIN IN HEMODIALYSIS PATIENTS: RELATIONSHIP TO}

\section{NUTRITIONAL STATUS}

by

\section{Annmarie Duggan}

Florida International University, 1997

\author{
Miami, Florida
}

Professor Fatma G. Huffman, Major Professor

The validity of serum transthyretin as a nutrition assessment parameter in hemodialysis patients was investigated. Fifty-one subjects (39\% male and $61 \%$ female; $53 \%$ black, $28 \%$ white, $12 \%$ Hispanic, $7 \%$ Other) receiving hemodialysis for $30 \pm 24$ months (mean $\pm S D$ ) and a total of $36 \pm 26$ months of renal replacement therapy were followed for six months. Serum transthyretin, albumin, BUN, creatinine, cholesterol, normalized protein catabolic rate (nPCR), KT/V, weight and 24 hour urine analysis were determined monthly. Etiologies of end stage renal disease were diabetic nephropathy (37\%), hypertensive nephrosclerosis $(37 \%)$. glomerulonephritis $(12 \%)$, polycystic kidney disease $(4 \%)$, lupus nephritis $(4 \%)$, other causes $(6 \%)$. A significant correlation was found between transthyretin and creatinine, albumin and loss of dry weight $(p<0.05)$. Transthyretin levels $<30 \mathrm{mg} / \mathrm{dl}$ were found to correlate with urine outputs $>240 \mathrm{cc} / 24$ hours, predialysis BUN $<50 \mathrm{mg} / \mathrm{dl}$ and $\mathrm{nPCR}<0.8 \mathrm{gm} / \mathrm{kg} / \mathrm{day}(\mathrm{p}<0.05)$. Transthyretin levels were higher in nondiabetics for all six months (significant in two/six months). No significant correlation was found between transthyretin and age, gender, race, months of hemodialysis, cholesterol or $\mathrm{KT} / \mathrm{V}$. Transthyretin levels may be used as an additional assessment parameter to identify hemodialysis patients who may benefit from nutritional intervention. 
I. INTRODUCTION ............................

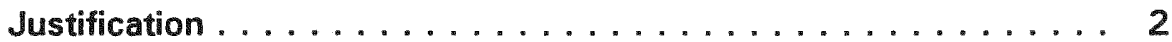

Purpose of Research ...................... 2

II. HYPOTHESIS TESTED . . . . . . . . . . . . . . . . . . . . 3

III. REVIEW OF THE LITERATURE . . . . . . . . . . . . . . . . . 4

Transthyretin Levels and Nutritional Status . . . . . . . . . . . . . . 4

Transthyretin Levels and Chronic Renal Failure . . . . . . . . . . . 5

Transthryretin Levels- Predictor of Morbidity and Mortality . . . . . . . 6

IV. METHODOLOGY ............................ 8

Subjects and Setting ...................... 8

Demographic and Clinical Data Collection ............. 8

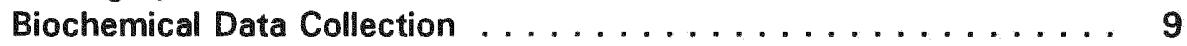

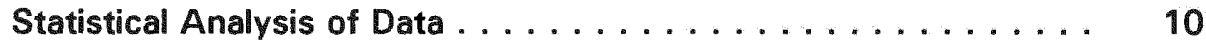

v. RESULTS ................................. 11

VI. Discussion ............................. 22

VII. SUMMARY, CONCLUSION, RECOMIMENDATIONS . . . . . . . 25

LIST OF REFERENCES ........................ 26

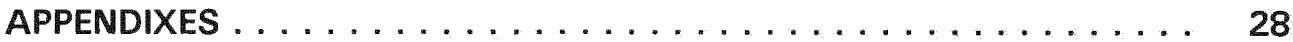

A. Informed Consent (English) . . . . . . . . . . . . . . . . 29

B. Informed Consent (Spanish) .................. 31

C. Instructions for Urine Collection (Spanish) . . . . . . . . . . . 33

D. Instructions for Urine Collection (English) . . . . . . . . . . 34 
Table 1. Demographics of Hemodialysis Patients. . . . . . . . . . . . . . . . 12

Table 2. Primary Etiology of End Stage Renal Disease . . . . . . . . . . . . . 13

Table 3. Nutritional Parameters of Subjects . . . . . . . . . . . . . . . . . . 14

Table 4. Relationship of Transthyretin with Other Nutrition Parameters . . . . . . . 16

Table 5. Categorical Relationship of Transthyretin with Nutrition Parameters . . . . . 17

Table 6. Comparison of Nutrition Parameters Between Diabetics and Non-Diabetics . 21

Figure 1. Transthyretin Mean of 6 Months. . . . . . . . . . . . . . 15

Figure 2. Comparison of Albumin and Transthyretin Levels Over 6 Months . . . . . . 19

Figure 3. Comparison of Transthyretin in Diabetics and Non-Diabetics Over 6 Months 20 


\section{INTRODUCTION}

Despite advances in the provision of renal replacement therapy, there still remains a high morbidity and mortality rate in hemodialysis patients. Increasing evidence links poor nutritional status to the increased morbidity and mortality observed in the hemodialysis patient $(1,2)$.

Nutritional assessment is important to identify the patient with or at risk for malnutrition. Low levels of serum albumin and cholesterol have been shown to be strong predictors of mortality in the dialysis population (2). These biochemical markers reflect long term malnutrition and may not accurately reflect early signs of inadequate protein and energy intake $(1,3)$. A low serum level of transthyretin (formerly known as prealbumin) has also been shown to be an independent predictor of morbidity (4) and mortality (4-6) in the hemodialysis patient. Transthyretin levels are an early indicator of adequate or inadequate nutritional intake (7), an index for the provision of adequate nutritional support $(7,8)$ and a marker for visceral protein anabolism $(8)$. Since serum transthyretin has a half life of two days and responds rapidly to increased or decreased nutritional intake (7), it has been proposed as a short term marker of nutritional adequacy in the hemodialysis patient.

The protein catabolic rate (PCR) is a common parameter used to evaluate recent nutritional intake in hemodialysis patients. PCR is derived through urea kinetic modeling from the urea generation rate and expressed as normalized PCR (nPCR) in relation to body weight. If the patient is in a steady state, PCR is a reflection of dietary protein intake, thereby serving as an early marker of inadequate protein intake (9). In a recent study examining the relationship of serum levels of transthyretin with dietary protein intake in hemodialysis patients, a correlation was found between low transthyretin levels $(<30 \mathrm{mg} / \mathrm{dl})$ and lower protein catabolic rates (nPCR) $<1.2 / \mathrm{gm} / \mathrm{kg}(10)$. This finding merits further investigation and additional research to validate the correlation between low transthyretin and low protein catabolic rate. 


\section{JUSTIFICATION}

A very limited amount of information has been published regarding the use of serum transthyretin as an early marker of malnutrition in the hemodialysis population. Even less information is available regarding the correlation of PCR with serum transthyretin levels. If low serum levels of transthyretin correlate with inadequate dietary protein as evidenced by low protein catabolic rates, serum transthyretin would serve as an easily accessible early indicator for aggressive nutrition intervention. The routine drawing of serum transthyretin levels in hemodialysis patients for nutritional assessment purposes would be justified by the above findings.

\section{PURPOSE OF RESEARCH}

The purpose of this study was to confirm the use of serum transthyretin as a valid early marker of poor nutritional status in the hemodialysis patient and to validate the correlation of low serum transthyretin levels with established nutrition assessment parameters and lower protein catabolic rates. 


\section{HYPOTHESIS TESTED}

\section{Primary:}

1. Serum transthyretin levels less than $30 \mathrm{mg} / \mathrm{dl}$ correlate with normalized protein catabolic rates less than $1.0 \mathrm{gm} / \mathrm{kg}$ body weight/day.

2. Low serum transthyretin levels correlate with low predialysis blood urea nitrogen.

3. Transthyretin levels increase/decrease prior to changes in serum albumin levels and cholesterol levels.

\section{Secondary:}

1. Serum transthyretin levels less than $30 \mathrm{mg} / \mathrm{dl}$ are indicative of inadequate energy intake as evidenced by a decrease in dry weight and body mass index.

2. There is no difference in transthyretin levels based on age, race, length of time on dialysis, or diabetic status. 


\section{REVIEW OF THE LITERATURE}

The relationship between malnutrition and increased morbidity and mortality has been well established in the hemodialysis population $(1,2)$. The nutrition markers, cholesterol and serum albumin, have been shown to have a strong predictive value of outcome in hemodialysis patients $(2,11)$. Goldwasser et al. found that single measurements of albumin and cholesterol are independent predictors of survival for at least two years in both recently diagnosed and longstanding dialysis patients and these markers remain predictive even in patients receiving adequate dialysis (12). These biochemical markers reflect long term malnutrition and may not accurately identify the early signs of inadequate protein and energy intake $(1,3)$. A valid short term indicator of malnutrition is needed for early identification of the hemodialysis patient at risk.

\section{Transthyretin Levels and Nutritional Status}

Serum transthyretin, also known as thyroxine-binding prealbumin or prealbumin, has been proposed as an early indicator of nutritional status in hemodialysis patients $(4,6,13,14)$. Transthyretin, with a molecular weight of 54,000 , is synthesized primarily in the liver and circulates as a stable and symmetrical tetramer composed of four tryptophan rich identical subunits of 127 amino acids each $(15,16)$. Transthyretin serves as a transport protein for thyroxine (T4) and a carrier protein for retinol binding protein and therefore vitamin $A$. Transthyretin levels in serum increase or decrease in relation to the adequacy of protein or energy intake. Transthyretin decreases rapidly in response to lowered energy or protein intake, even when protein intake is inadequate for a little as three days (15).

Transthyretin may have advantages over the use of either albumin or transferrin as a short term marker of nutritional adequacy. Transthyretin has a short half life of two days, high tryptophan content, high proportion of essential to nonessential amino acids and small pool size. It is therefore thought to be a better indicator of visceral protein status and positive nitrogen balance than albumin or transferrin (17). Concentrations of transthyretin also are not 
significantly influenced by fluctuations in hydration status which is of clinical significance for hemodialysis patients (15).

\section{Transthyretin Levels in Chronic Renal Failure}

Elevated levels of transthyretin have been observed in patients with chronic renal failure (18). Previously it was thought that the elevated transthyretin levels seen in hemodialysis versus healthy controls discounted its use as a nutritional marker in this population. Cano et al. (18) concluded that the elevated transthyretin levels seen in chronic renal failure were related to alterations in the degradation of prealbumin-retinol binding protein complex. During uremia, the increase in plasma retinol binding protein is responsible for an increase in the prealbumin fraction bound to the prealbumin-retinol-binding protein-retinol complex. The subsequent reduction of free prealbumin may account for the decrease in prealbumin breakdown and the increase in total plasma transthyretin (19). If adjustment is made for an altered physiological range, transthyretin concentrations correlate with nutrition status of patients with a stable degree of renal failure, such as that found in hemodialysis patients $(4,18)$. Also, if a trend in the direction of change is noted, despite the elevated levels seen in renal failure, the changes are likely to reflect alterations in nutritional status and nitrogen balance (15).

In studies involving hemodialysis patients, transthyretin levels have been found to correlate with other established nutrition assessment parameters, further supporting its use as a nutrition indicator in this population $(4-6,20)$. Jacob et al. (20) confirmed the value of transthyretin as a marker of under nutrition through its correlation with both triceps skin fold thickness and midarm muscle circumference. Cano et al. (4) in the statistical selection of nutrition parameters in hemodialyzed patients demonstrated that a serum transthyretin $<0.30$ gram /liter correlated with body weight, arm muscle circumference, triceps skin fold, albumin and creatinine (4). Avram et al. (5) also found that serum transthyretin correlated strongly with other baseline biochemical markers - albumin, creatinine and cholesterol. Cano et al. (10) in their study of the relation of serum transthyretin levels and protein intake in hemodialysis patients, found that a serum 
transthyretin level $<0.30 \mathrm{~g} /$ liter corresponded to a protein catabolic rate $(\mathrm{nPCR})$ of $<1.2 \mathrm{~g} / \mathrm{kg} / \mathrm{day}$ with a lack of correlation seen between these two variables when nPCR exceeded $1.4 \mathrm{~g} / \mathrm{kg} / \mathrm{day}$. Vehe et al. (21) in a study of nutrition support in infected patients with chronic renal failure found that transthyretin correlated significantly with cumulative intakes of both protein and energy.

\section{Transthyretin Level- A Predictor of Morbidity and Mortality}

Transthyretin levels have also been demonstrated to have predictive value for morbidity and mortality in hemodialysis and peritoneal dialysis patients. Avram et al. (5) in a seven year prospective study, found that patients with serum transthyretin levels of $30 \mathrm{mg} / \mathrm{dl}$ or above had a survival rate of over $80 \%$ at 40 months, versus patients with baseline values lower than 30 $\mathrm{mg} / \mathrm{dl}$, who had only $40 \%$ survival rate. It was concluded that a low level of serum transthyretin was an important and independent predictor of mortality risk for hemodialysis and peritoneal dialysis patients followed up to 40 months. Cano et al. (4) demonstrated that low levels of serum transthyretin but not albumin or anthropometrics were associated with increased mortality in hemodialysis patients. A serum transthyretin less than $0.30 \mathrm{~g} /$ liter predicted both infection and mortality risks with high sensitivity and specificity.

Goldwasser et al. (6) concluded that transthyretin was actually a stronger independent correlate of mortality risk than albumin concentration. Transthyretin concentration may be more reflective of a distinct aspect of mortality risk than albumin, or albumin concentration may be more influenced by factors unrelated to mortality risk. The increased predictive power was also attributed to the shorter half-life of serum transthyretin, permitting rapid changes in its concentration in response to under nutrition or catabolism. Sreedhara et al. (22) found that there was a higher relative risk of death in hemodialysis patients with a serum transthyretin $<30 \mathrm{mg} / \mathrm{dl}$. A single measurement of transthyretin was found to predict patient survival for up to five years. Jacob et al. (20) found that transthyretin levels of $0.30 \mathrm{~g} /$ liter were fairly sensitive in identifying wasted patients as well as those with a history of recent infection, yet IGF-1 had a higher predictive value. Jacob et al. (20) also found that patients with a history of infection in the prior 
six months had lower intakes of protein and calories as well as lower serum concentrations of transthyretin and IGF-1 when compared with the infection-free patients.

These findings support that a low serum transthyretin level in hemodialysis patients is correlated with increased morbidity and mortality, lower protein catabolic rate and is a valid marker of visceral protein status if altered physiological ranges are taken into account. 


\section{METHODOLOGY}

\section{Study Design}

This was a prospective, cohort, correlation, nonintervention study utilizing convenience sampling. The study was approved by the Florida International University Institutional Review Board prior to implementation.

\section{Subjects and Setting}

Patients were selected from a population of seventy seven patients receiving hemodialysis treatments at Complete Dialysis Care, Inc., a free standing outpatient dialysis clinic in Coral Springs, Florida. A convenient sample of fifty one patients were enrolled in June 1996 after meeting the following eligibility criteria: (1) have received hemodialysis treatments for greater than 3 months, (2) receive thrice weekly hemodialysis treatments, (3) absence of impaired hepatic function, (4) absence of chronic infection, inflammatory syndromes or infections in the three months prior to the study, (5) not taking corticosteroids, (6) willingness to participate in the study as evidenced by signing of an Informed Consent. Subjects were followed for six months. Those who developed infection within the six month study period were excluded from the study. Forty three patients completed the six month study period. Four patients discontinued due to infection, one due to noncompliance with treatments, one expired, one underwent kidney transplantation and one transferred to another facility.

\section{Demographic and Clinical Data Collection}

Demographic data included age, gender and race. Clinical data included:

(1) etiology of end stage renal disease obtained from the HCFA 2728 form in the patients' chart,

(2) total months on hemodialysis determined by calculating the number of months between the first outpatient dialysis treatment and the first month of data collection, (3) diabetic condition as defined as the history of a diagnosis of non-insulin dependent or insulin dependent diabetes 
mellitus, (4) measured height, (5) post-dialysis weight was recorded on the day of the monthly lab collection for each month of the study. Body Mass Index (Quetelet's Index) was determined by weight in $\mathrm{kg}$ divided by height in meters squared.

\section{Biochemical Data Collection}

Biochemical data was obtained from routine monthly midweek blood specimens for six consecutive months. Normalized protein catabolic rate and KT/V were calculated for the last three consecutive months of the study period utilizing three blood urea nitrogen levels (BUN). Pre and post dialysis BUN was drawn after the first treatment of the week (Monday) to calculate $\mathrm{nPCR}$ and $\mathrm{KT} / \mathrm{N}$. The dialysis machine blood pump flow was lowered to $100 \mathrm{cc} /$ minute for exactly one minute prior to drawing the post dialysis BUN specimen.

Prior to the second treatment of the week (Wednesday), serum albumin, transthyretin, creatinine, cholesterol and predialysis BUN levels were obtained. Serum was analyzed at REN Laboratories, Fort Lauderdale, Florida by the following methods: blood urea nitrogen - urease, albumin - bromcresol green (BCG) dye binding, cholesterol - enzymatic hydrolysis with cholesterol ester hydrolase, cholesterol oxidase and peroxidase, creatinine - Jaffe method. Serum transthyretin was determined by nephelemetry. The nPCR was calculated utilizing the Mistebar Urea Kinetics Analysis Program for the PC (Mistebar Computer Consultants, Inc., Las Cruces, NM).

Urine specimens were obtained for all patients who had urine outputs $>240 \mathrm{cc}$ in twenty four hours. The twenty four hour urine volume was recorded and urine was analyzed for urine urea nitrogen (method - urease enzyme) and total urinary protein (method - benzethonium chloride). 


\section{Statistical Analysis}

Population frequencies were calculated for race, gender, etiology of end stage renal disease and diabetic status. The mean and standard deviations were determined for age, months of hemodialysis, total months of renal replacement therapy, dry weight, body mass index, weight change over six months, transthyretin, albumin, cholesterol, BUN, KT/V, and nPCR. Cholesterol levels for patients taking cholesterol lowering medications were eliminated from all statistical analysis.

Correlation data is expressed as Pearson correlation coefficients ( $r$ ) unless otherwise indicated. Correlations were examined between transthyretin levels and $\mathrm{nPCR}$, age, gender, race, diabetic status, dry weight, body mass index, albumin, cholesterol, creatinine, BUN, KTN, urinary protein and dry weight loss. Fishers Exact Test, Student's t-test and Chi-squared test were utilized for categorical data analysis utilizing a cutoff value of transthyretin less than 30 $\mathrm{mg} / \mathrm{dl}$ as per Cano et al. $(4,10)$.

Calculations were performed using the Statistical Package for the Social Sciences Version 4.1 software. 


\section{RESULTS}

Demographic data is included in Table 1. The mean age of the population was $60 \pm 17$ years. The patients had received $30 \pm 24$ months (mean \pm SD) of hemodialysis therapy and a total of 36 \pm 26 months (mean $\pm S D$ ) of renal replacement therapy. Forty three percent of the subjects had diabetes. Sixty one percent were female, thirty nine percent were male. The ethnic distribution was as follows: $28 \%$ white, $53 \%$ black, $12 \%$ Hispanic, $7 \%$ Other. The etiologies of end stage renal disease are listed in Table 2 and include diabetic nephropathy (37\%), hypertensive nephrosclerosis (37\%), glomerulonephritis (12\%), polycystic kidney disease (4\%), lupus nephritis (4\%). There was no significant correlation between serum transthyretin levels and age, race, gender, months of hemodialysis, length of time receiving renal replacement therapy or etiology of end stage renal disease.

The mean and standard deviations of study parameters of the subjects for the six month study period are given in Table 3. The distribution of the mean transthyretin level over six months is illustrated in Figure 1. The overall mean transthyretin level for all subjects in six months was $32.4 \pm 6.8 \mathrm{mg} / \mathrm{dl}$. This is above the acceptable level in the hemodialysis population of $30 \mathrm{mg} / \mathrm{dl}$. Sixty-four percent of the subjects had a mean transthyretin level above $30 \mathrm{mg} / \mathrm{dl}$ and thirty-six percent had mean levels less than $30 \mathrm{mg} / \mathrm{dl}$ for the six month study period (Figure 1).

Pearson correlation coefficients for the relationship of transthyretin with other nutrition parameters are listed in Table 4. There was a statistically significant positive correlation between serum transthyretin and serum albumin $(r=0.524, p=0.000)$, serum creatinine $(r=0.464, p=0.000)$ and loss of dry body weight $(r=0.339, p=0.032)$. Categorical data analysis is listed in Table 5. There was a significant and positive correlation, utilizing Fishers Exact Test, between transthyretin levels $<30 \mathrm{mg} / \mathrm{dl}$ and predialysis BUN levels $<50 \mathrm{mg} / \mathrm{dl}(p=0.017)$, urine output $>240 \mathrm{cc}$ in twenty four hours $(p=0.039)$ and with $n P C R<0.8 \mathrm{gm} / \mathrm{kg} / \mathrm{day}(p<0.05)$. 
TABLE 1. Demographics of Hemodialysis Patients ( $n=51)$

\begin{tabular}{|ll|l|}
\hline Variables: & Percent \\
\hline Race: & White & $28 \%$ \\
& Black & $53 \%$ \\
& Hispanic & $12 \%$ \\
& Other & $7 \%$ \\
Gender: & Male & $39 \%$ \\
& Female & $61 \%$ \\
Diabetes: & Non-diabetics & $57 \%$ \\
& Diabetic & $43 \%$ \\
\hline & Range & Mean \pm SD \\
\hline Age: & $18-86$ years & $60 \pm 17$ \\
& & \\
\hline Months on hemodialysis: & & $30 \pm 24$ \\
& $3-113$ months & \\
\hline Months of renal & & \\
replacement therapy: & & $36 \pm 26$ \\
\hline
\end{tabular}


TABLE 2. Primary Etiology of End Stage Renal Disease $(n=51)$

\begin{tabular}{|l|l|}
\hline Variables & Percent \\
\hline Diabetic Nephropathy & $37 \%$ \\
Hypertensive Nephrosclerosis & $37 \%$ \\
Glomerulonephritis & $12 \%$ \\
Polycystic Kidney Disease & $4 \%$ \\
Lupus Nephritis & $4 \%$ \\
Other & $6 \%$ \\
\hline & $100 \%$ \\
\hline
\end{tabular}




\section{TABLE 3. Nutritional Parameters of Subjects ${ }^{1}$}

\begin{tabular}{|c|c|c|c|}
\hline Nutritional Parameter & Range of Data. & Mean SD & Goal Range \\
\hline Transthyretin (mg/dl) & $18-47$ & $32 \pm 7$ & $>30$ \\
\hline Albumin (gm/dl) & $3.36-4.63$ & $3.95 \pm 0.26$ & $3.5-4.5$ \\
\hline $\begin{array}{l}\text { Predialysis blood urea } \\
\text { nitrogen (mg/dl) }\end{array}$ & $27-93$ & $62 \pm 13$ & $60-80$ \\
\hline $\begin{array}{l}\text { Serum creatinine } \\
\text { (mg/dl) }\end{array}$ & $5.3-22$ & $11.4 \pm 3.4$ & N/A \\
\hline Cholesterol (mg/dl) & $80-375$ & $172 \pm 51$ & $150-200$ \\
\hline$K T N^{\star \star}$ & $1.1-2.9$ & $1.47 \pm 0.28$ & $>1.2$ \\
\hline nPCR (gm/kg/day) & $0.67-1.8$ & $1.04 \pm 0.24$ & 1.0-1.4 \\
\hline Body weight $(\mathrm{kg})$ & $40-140$ & $74 \pm 20$ & N/A \\
\hline Body Mass Index ${ }^{\star \star *}$ & 14-51 & $27 \pm 8$ & N/A \\
\hline $\begin{array}{l}\text { Dry weight change over } \\
6 \text { month study period } \\
\text { (kg.) }\end{array}$ & $-4.6-+7.1$ & $+0.28 \pm 2.51$ & N/A \\
\hline
\end{tabular}




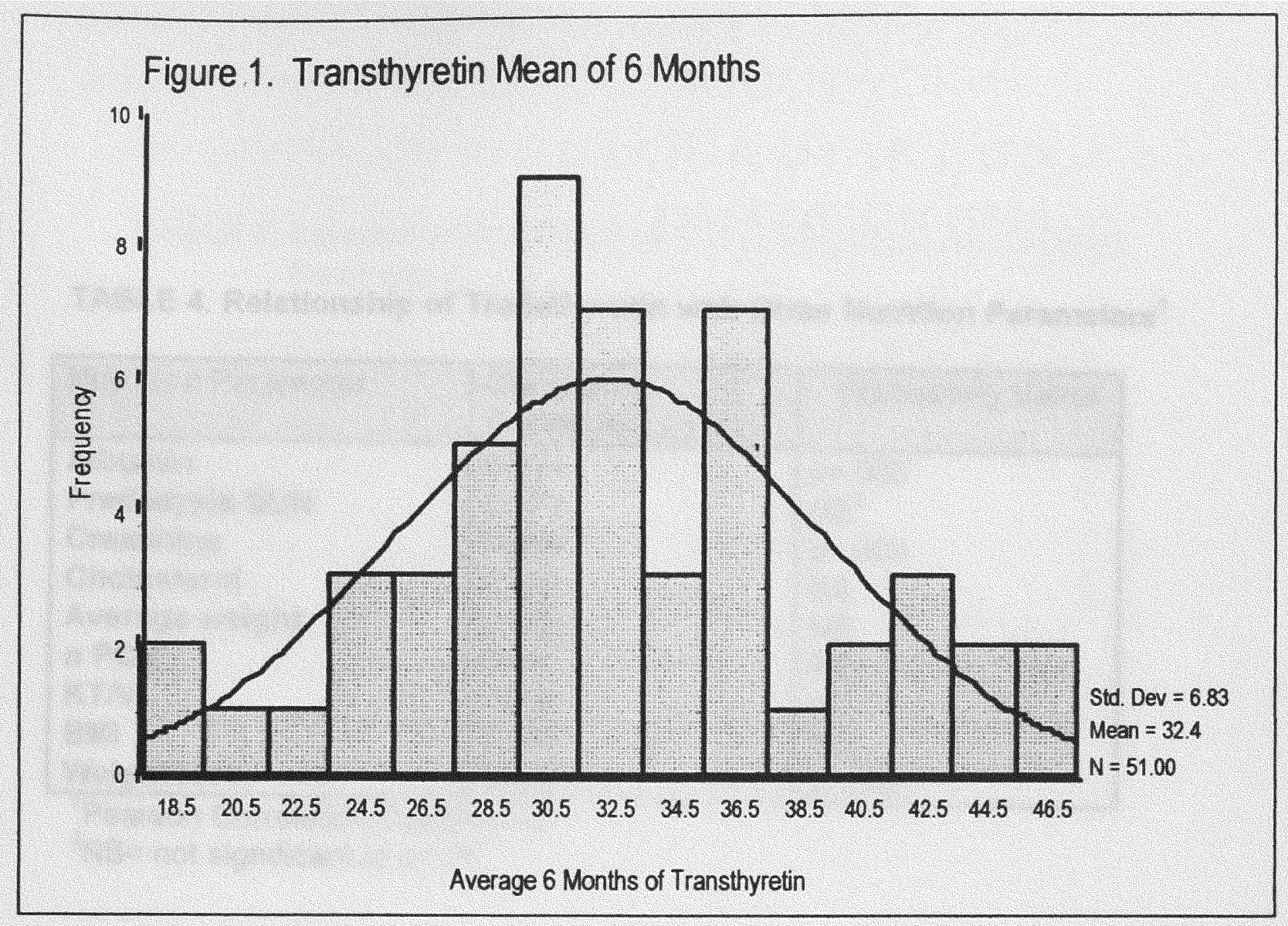


TABLE 4. Relationship of Transthyretin with Other Nutrition Parameters ${ }^{1}$

\begin{tabular}{|l|l|l|}
\hline Nutrition Parameter & $\begin{array}{l}\text { Correlation } \\
\text { Coefficient }(\mathbf{r})\end{array}$ & Probability Value \\
\hline Albumin & 0.524 & $\mathrm{p}=.000$ \\
Predialysis BUN & 0.183 & NS \\
Creatinine & 0.464 & $\mathrm{p}=.000$ \\
Cholesterol & 0.128 & NS \\
Average weight & 0.262 & NS \\
n PCR & 0.132 & NS \\
KT/N & 0.042 & NS \\
BMI & 0.253 & NS \\
Weight loss & 0.339 & p $=.032$ \\
\hline
\end{tabular}

'Pearson Correlation Coefficients

${ }^{2} \mathrm{NS}=$ not significant at $p<.05$ 
TABLE 5. Categorical Relationship of Transthyretin with Nutrition Parameters ${ }^{1}$

\begin{tabular}{|l|l|}
\hline Nutrition Parameter & Transthyretin $<30 \mathrm{mg} / \mathrm{dl}$ \\
\hline Urine Output $>240 \mathrm{cc}(\mathbf{2 4} \mathrm{hrs})$ & $\mathrm{p}=0.039$ \\
Albumin $<3.5 \mathrm{gm} / \mathrm{dl}$ & $\mathrm{NS}$ \\
Predialysis BUN $<50 \mathrm{mg} / \mathrm{dl}$ & $\mathrm{p}=0.017$ \\
Cholesterol $<150 \mathrm{mg} / \mathrm{dl}$ & $\mathrm{NS}$ \\
$\mathrm{n} \mathrm{PCR}<0.8(\mathrm{gm} / \mathrm{kg} /$ day) & $\mathrm{P}=0.03$ \\
$\mathrm{KT} / \mathrm{V}<1.2$ & $\mathrm{NS}$ \\
\hline
\end{tabular}

${ }^{1}$ Fishers Exact Test

${ }^{2}$ Significant at $\mathrm{P}<.05$ 
No statistically significant correlations were found between transthyretin $<30 \mathrm{mg} / \mathrm{dl}$ and serum cholesterol $<150 \mathrm{mg} / \mathrm{dl}$ or $\mathrm{KTN}<1.2$.

Figure 2. depicts the mean albumin levels and the mean transthyretin levels for each month of the study period. The mean transthyretin level dropped below the acceptable range of 30 $\mathrm{mg} / \mathrm{dl}$ in month 4 without any noticeable change in the mean

albumin level. Also, thirty-five percent of the subjects $(18 / 51)$ had a six month mean transthyretin level $<30 \mathrm{mg} / \mathrm{dl}$ despite a six month mean albumin level $>3.5 \mathrm{gm} / \mathrm{dl}$. In addition (not depicted in a table), there was a positive association between changes in levels of serum albumin and changes in levels of transthyretin between each month of the study period (Pearson correlation coefficient range $=0.284-0.621$ ). As the mean transthyretin increased, the mean albumin increased and as transthyretin decreased, the mean albumin decreased. This was statistically significant for four out of the five monthly intervals (range $p=0.000-p=0.024$ ).

A comparison of transthyretin levels (Student's t-test) in diabetics versus non-diabetics is shown in Figure 3. Transthyretin levels were higher in non-diabetics than diabetics for all six months, yet this was only statistically significant $(p<0.05)$ in two out of the six months. A comparison of other nutrition parameters between diabetics and non-diabetics is shown in Table 6. Mean creatinine levels $(p=0.02)$ were significantly lower in diabetics versus non-diabetics and BMI was significantly higher in diabetics $(p=0.034)$. Mean predialysis BUN and nPCR were lower in diabetics, although this was not statistically significant. Females $(p=0.018)$ had significantly higher BMI values than males. Mean creatinine levels $(p<.001), B M I(p=.018)$ and body weights $(p=.002)$ were significantly lower in whites than blacks (Students t-test). Mean creatinine levels were also found to be significantly lower in the nine patients who urinated $>240$ $c c$ in 24 hours $(p<.001)$. There was no significant difference in creatinine levels or transthyretin levels between men and women. 
Figure 2. Comparison of Albumin and Transthyretin Levels Over 6 Months

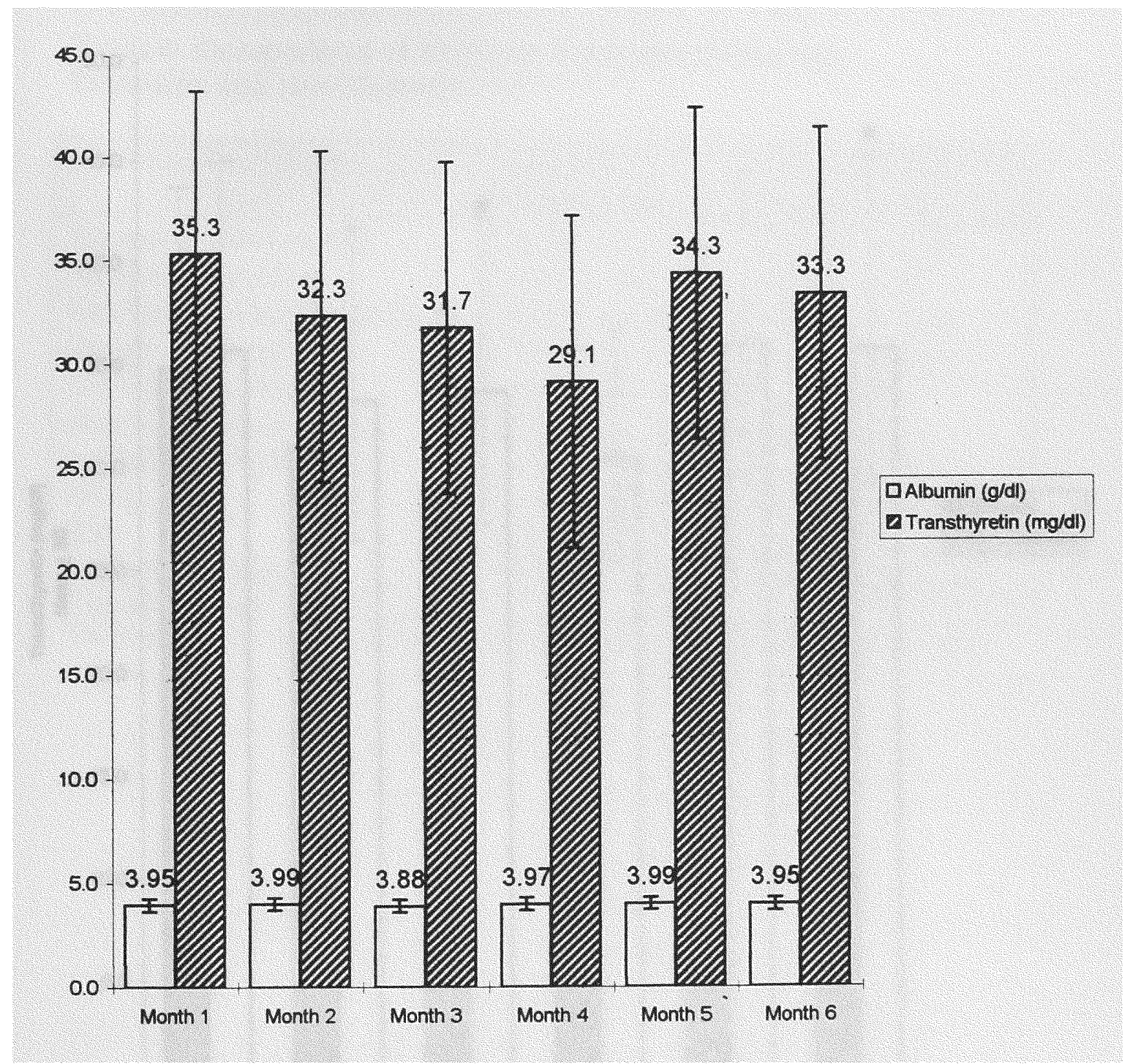


Figure 3. Comparison of Transthyretin in Diabetics and Non-Diabetics Over 6 Months ${ }^{* *}$

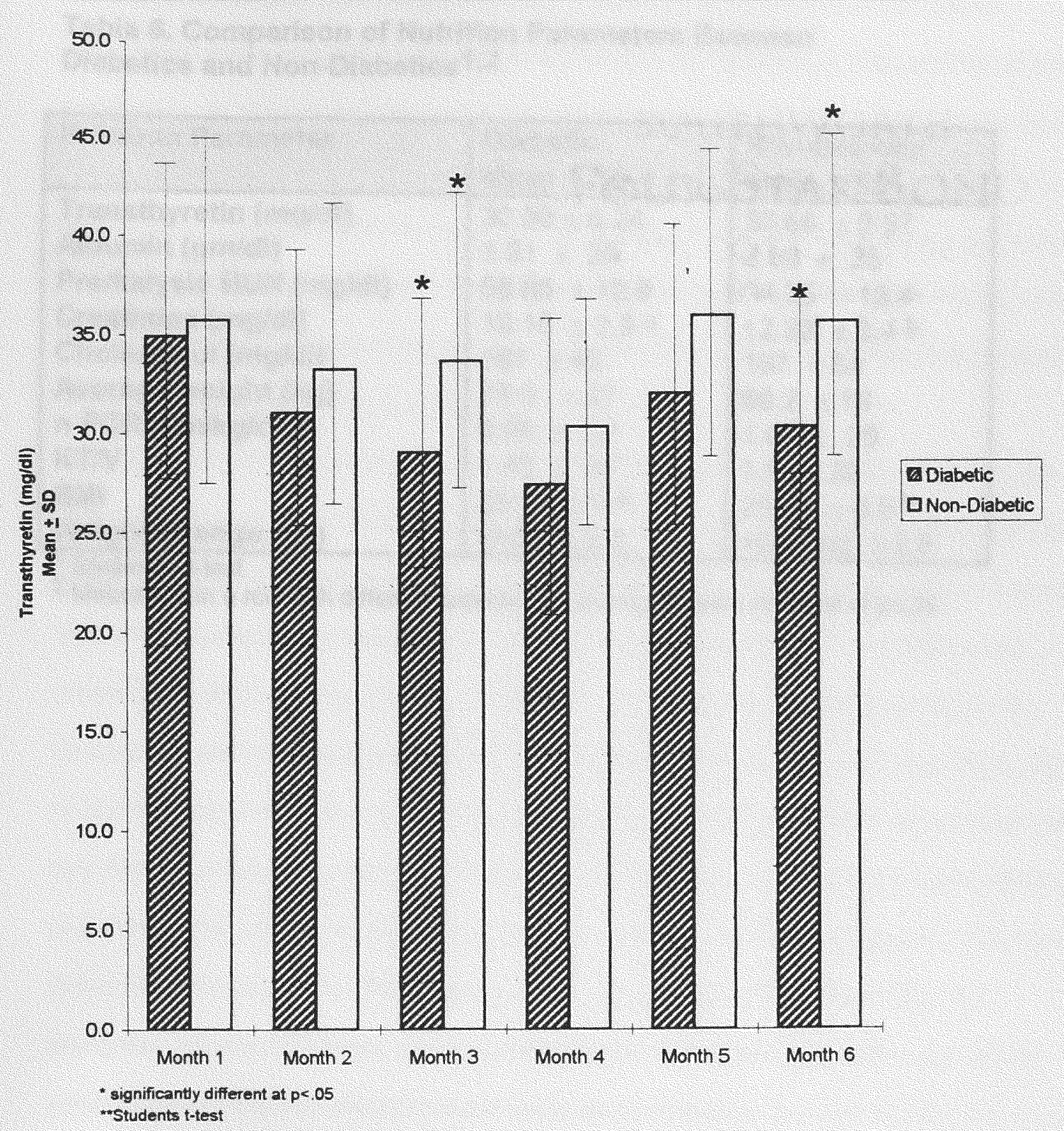


Table 6. Comparison of Nutrition Parameters Between Diabetics and Non-Diabetics 1,2

\begin{tabular}{|c|c|c|}
\hline Nutrition Parameter & $\begin{array}{l}\text { Diabetic } \\
\text { Mean I SB }\end{array}$ & $\begin{array}{l}\text { Non Diabetic } \\
\text { Mean I SD }\end{array}$ \\
\hline Transthyretin (mg/dl) & $30.59 \pm 6.24$ & $33.66 \pm 6.97$ \\
\hline Albumin (gm/dl) & $3.91 \pm .25$ & $3.98 \pm .25$ \\
\hline Predialysis BUN (mg/dl) & $58.65 \pm 12.9$ & $64.35 \pm 13.4$ \\
\hline Creatinine (mg/dl) & $10.15 \pm 2.9 a$ & $12.32 \pm 3.4^{b}$ \\
\hline Cholesterol (mg/dI) & $181 \pm 45$ & $167 \pm 54$ \\
\hline Average weight (kg) & $79.9 \pm 21$ & $69.2 \pm 19$ \\
\hline n PCR (gm/kg/day) & $0.98 \pm .22$ & $1.07 \pm .26$ \\
\hline KTN & $1.43 \pm .21$ & $1.5 \pm .32$ \\
\hline BMI & $29.53 \pm 8 a$ & $25.05 \pm 6.5 b$ \\
\hline Weight change (kg) & $-0.08 \pm 2.2$ & $+0.60 \mathrm{~kg} \pm 2.8$ \\
\hline
\end{tabular}

1 Student's t-test

2 Means within a row with different superscripts are significantly different at $p<.05$ 


\section{DISCUSSION}

This study confirms the usefulness of transthyretin as a marker of nutritional adequacy in hemodialysis patients. The strong correlation of serum transthyretin with other nutrition assessment parameters, serum albumin and creatinine, is in agreement with previous studies of transthyretin by other investigators $(4-6,22)$. The correlation of serum transthyretin with serum creatinine and albumin also supports its significance as a prognostic indicator. Creatinine, which reflects lean body mass, and serum albumin, which reflects visceral protein stores, have both been found to be inversely correlated with mortality in the hemodialysis population (2). A single measurement of transthyretin less than $30 \mathrm{mg} / \mathrm{dl}$ has been found to be an independent predictor of mortality in the hemodialysis population $(4-6,22)$.

The hypothesis that low levels of serum transthyretin would correlate with low predialysis BUN was accepted. The correlation in the present study between transthyretin $<30 \mathrm{mg} / \mathrm{dl}$ with predialysis BUN $<50 \mathrm{mg} / \mathrm{dl}$ and $\mathrm{nPCR}<0.8 \mathrm{gm} / \mathrm{kg} /$ day supports that transthyretin levels drop in response to inadequate protein intake. The hypothesis that transthyretin $<30 \mathrm{mg} / \mathrm{dl}$ would correlate with $\mathrm{nPCR}<1.0 \mathrm{gm} / \mathrm{kg} /$ day was rejected. A statistically significant correlation of transthyretin with $\mathrm{nPCR}$ was only found at $\mathrm{nPCR}<0.8 \mathrm{gm} / \mathrm{kg} /$ day in this cohort, whereas Cano et al. (10) found a correlation of transthyretin $<30 \mathrm{mg} / \mathrm{dl}$ and nPCR levels of $<1.2 \mathrm{gm} / \mathrm{kg} / \mathrm{day}$. This may have been due to the use of a smaller sample size in the present study and the finding that only $14 / 51(28 \%)$ of subjects had a three month mean nPCR level $>1.2 \mathrm{gm} / \mathrm{kg} /$ day. Fifty percent of the subjects had a mean nPCR between $0.8-1.2 \mathrm{gm} / \mathrm{kg} / \mathrm{day}$. The mean $\mathrm{nPCR}<0.8$ $\mathrm{gm} / \mathrm{kg} / \mathrm{day}$, found in twenty two percent of the subjects, was indicative of inadequate dietary protein intake to maintain visceral protein stores, as evidenced by the lower transthyretin levels. In hemodialysis patients nPCR values between $1.0-1.4 \mathrm{gm} / \mathrm{kg} / \mathrm{day}$ are desirable to maintain lean body mass (1). The National Cooperative Dialysis Study found that an nPCR $>1 \mathrm{gm} / \mathrm{kg} /$ day and a BUN $>50 \mathrm{mg} / \mathrm{dl}$ were associated with lower morbidity (23). Based on these findings, serum transthyretin may not replace $\mathrm{nPCR}$ as a short term indicator of nutritional adequacy, as it may 
miss patients with $\mathrm{nPCR}$ values between $0.8-1.0 \mathrm{gm} / \mathrm{kg} /$ day, yet it provides an additional marker for the need for nutrition intervention.

The hypothesis that serum transthyretin levels $<30 \mathrm{mg} / \mathrm{dl}$ would be indicative of inadequate energy intake as evidenced by loss of dry weight was accepted. The correlation between serum transthyretin and loss of dry body weight supports that serum transthyretin may be a marker of inadequate energy intake in patients who are receiving hemodialysis treatments. These findings are in agreement with Vehe et al. (21) where transthyretin correlated significantly with cumulative intakes of both protein and energy, in chronic renal failure patients receiving nutrition support. Transthyretin has been found to correlate with other markers of body mass such as the midarm muscle circumference $(4,13,20)$ and triceps skinfold thickness $(4,20)$.

A correlation was not found between inadequate dialysis and low transthyretin. This may have been due to an adequate three month mean $\mathrm{KT} / \mathrm{N}$ of $1.47 \pm 0.28$ and that only two patients (4\%) had a three month mean KTN of less than 1.2. Clearly there were not enough patients receiving inadequate dialysis to identify a statistically significant finding. It is recognized that the results involving KT/ and nPCR are also limited by the use of single-pool kinetic modeling.

Since transthyretin has a much shorter half life than albumin, we sought to evaluate whether transthyretin levels would rise or fall prior to changes in albumin levels. The hypothesis that transthyretin levels would increase or decrease prior to changes in albumin levels was rejected as a positive association was found between changes in levels of serum albumin and changes in levels of transthyretin. This may have been due to the monthly interval in which specimens were drawn. Since serum levels were only obtained on a monthly basis, changes in transthyretin levels (half-life 1-2 days) that may have occurred before changes in albumin levels (half-life 21 days) were not detected. The strong correlation between albumin and transthyretin levels and the correlation between changes in monthly transthyretin correlating with changes in albumin levels, could be interpreted as negating the advantages of measuring transthyretin as an additional nutrition indicator. Yet, the finding that thirty five percent of the subjects had six 
month mean transthyretin levels $<30 \mathrm{mg} / \mathrm{dl}$ despite a mean albumin level $>3.5 \mathrm{gm} / \mathrm{dl}$ justifies the use of transthyretin as a marker for patients requiring nutrition intervention that may not have been identified based on serum albumin levels alone. The early identification of patients with poor nutritional intake, through the measurement of serum transthyretin, would allow for early nutrition intervention thereby preventing a further decline in nutritional status and its associated higher morbidity and mortality. As patients with conditions that may influence transthyretin levels (such as the development of infection) were excluded from the study, the changes in transthyretin that occurred without changes in albumin, may be attributed to changes in nutritional intake of dietary protein or energy rather than an acute phase response.

Caution must be used in interpreting transthyretin levels in subjects who urinate $>240$ cc per day. These subjects were found to have significantly lower transthyretin levels. Subjects who urinated $>240 \mathrm{cc}$ per day also had significantly lower creatinine levels, yet no significant difference in serum albumin levels. A statistically significant inverse correlation was not found between total milligrams of urinary protein excreted per day and serum transthyretin levels. Findings of this study are limited by the small percentage of the cohort ( $9 / 51$ or $18 \%)$ who still urinated $>240 \mathrm{cc}$ per day. Therefore, more research is needed to clarify the interpretation of serum transthyretin as a nutritional marker in subjects who still have residual renal function and proteinuria.

The hypothesis that there would be no difference in transthyretin levels based on age, race and length of time on dialysis was accepted. In this patient cohort, the inverse correlation between age and transthyretin which was previously demonstrated by Sreedhara et al. (22) was not found. The positive correlation between transthyretin with total cholesterol found by other investigators $(5,6)$ was not confirmed in this cohort. This may have been due to a limited sample size in the present study. Transthyretin levels were lower in diabetics which is in agreement with Sreedhara et al. (22) therefore the hypothesis that there would be no difference in transthyretin levels between diabetics and nondiabetics was rejected. Yet, the lower transthyretin level in 
diabetics versus non-diabetics was only statistically significant in two out of the six months (Figure 3). Diabetics also had lower serum creatinine levels despite significantly higher body mass indexes. This may have been due to an excess of adiposity with a decrease in lean body mass in the diabetics, although body composition measurements were not performed to confirm this. As the presence of diabetes and the presence of low serum transthyretin are both independent predictors of mortality $(5,22)$, diabetic subjects who have low serum transthyretin levels represent a group who may benefit from prompt intervention to improve nutritional status.

The above findings are limited by the use of a convenient sample, a limited sample size and a short study period (6 months), assumption that single pool urea kinetic modeling accurately determines KTN and nPCR, and accuracy of the 24 hour urine collection by the subject. Despite these limitations, the findings support that despite the elevated levels of serum transthyretin in chronic renal failure, serum transthyretin is a useful nutrition assessment parameter after adjustment for altered physiological range.

\section{SUMMARY, CONCLUSIONS, RECOMMENDATIONS}

Measuring serial serum transthyretin levels in hemodialysis patients is a reliable method for identifying patients at nutritional risk, as well as patients at higher morbidity and mortality risk. Serum transthyretin may serve as a marker for those in need of nutritional intervention, who may not have been identified based on serum albumin alone. Future research is needed to determine the response of serum transthyretin to nutritional supplementation in the hemodialysis setting. 


\section{LIST OF REFERENCES}

1. Hakim RM, Levin N. Malnutrition in hemodialysis patients. Am $J$ Kidney Dis 1993;21(2):125-137.

2. Lowrie EG, Lewe NL. Death risk in hemodialysis patients: the predictive value of commonly measured variables and an evaluation of death rate differences between facilities. Am J Kidney Dis May 1990;15(5):458-482.

3. Blumenkranz MJ, Kopple JD, Gutman RA, Chan YK, Barbour GL, Robers C, Shen FH, Gandhi VC, Tucker T, Curtis FK, Coburn JW. Methods for assessing nutritional status of patients with renal failure. Am J Clin Nutr 1980; 33:1567-1585.

4. Cano N, Fernandez J, Lacombe P, Lankester M, Pascal S, Defayolle M, Labastie J, Saingra $S$. Statistical selection on nutritional parameters in hemodialyzed patients. Kidney Intl 1987;32(Suppl 22):S178-S180.

5. Avram MM, Mittman N, Bonomini L, Chattopadhyay J, Fein P. Markers for survival in dialysis: a seven year prospective study. Am J Kidney Dis 1995;26(1):209-219.

6. Goldwasser P, Michel MA, Collier J, Mittman N, Fein P, Gusik SA, Avram MM. Prealbumin and lipoprotein(a) in hemodialysis: relationships with patient and vascular access survival. Am $J$ kidney Dis 1993;22(1):215-225.

7. Ingenbleek $Y$, Visscher MD, Nayer PD. Measurement of prealbumin as index of proteincalorie malnutrition. Lancet July 1972:106-108.

8. Tuten MB, Wogt S, Dasse F, Leider $Z$. Utilization of prealbumin as a nutritional parameter. JPEN 1985;9(6):709-711.

9. Boran MF, Schoenfeld PY, Gotch FA, Sargent JA, Wolfson M, Humphrey H. Nitrogen balance during intermittent dialysis therapy of uremia. Kidney Intl 1978;14:491-500.

10. Cano N, Stroumza P, Lacombe P, Labastie-Coeyrebourcq J, Durbec JP. Serum transthyretin and protein intake in haemodialysis patients (letter). Nephrol Dial Tranplant 1992; 7(10):1069-1070.

11. Kaminski MV, Lowrie EG, Rosenblatt SG, Haase T. Malnutrition is lethal, diagnosable and treatable in ESRD patients. Transpl Proc 1991;23(2):1810-1815.

12. Goldwasser P, Mittman N, Antignani A, Burrell D, Michel MA, Collier JC, Avram MM. Predictors of mortality in hemodialysis patients. J Am Soc Nephrol 1993;3:1613-1622.

13. Oksa H, Ahonen K, Pasternack A, Marnela KM. Malnutrition in hemodialysis patients. Can J Urol Nephrol 1991;25:157-161.

14. Young G, Swanepoel CR, Croft MR, Hobso SM, Parsons FM. Anthropometry and plasma valine, amino acids and proteins in the nutritional assessment of hemodialysis patients, Kidney IntI 1982;21:492-499.

15. Spiekerman AM. Proteins used in nutritional assessment. Clin Lab Med 1993;13(2):353369. 
16. Ingenbleek $Y$, Young $V$. Transthyretin (prealbumin) in health and disease: nutritional implications. Annu Rev Nutr 1994;14:495-533.

17. Benjamen DR. Laboratory tests and nutritional assessment : protein-energy status. Ped Clin N Amer 1989;36:139-161.

18. Cano N, Dicostanzo-Dufetel J, Calaf R, Durbec JP, Lacombe P, Pascal S, Stroumza P, Labastie-Coeyrehourcq J. Prealbumin-retinol-binding-protein-retinol complex in hemodialysis patients. Am J Clin Nutr 1988;47:664-667.

19. Cano N, Stroumza P, Lacombe P, Labastie-Coeyrehourcq J. Plasma prealbumin in hemodialysis patients (letter). Am J Kidney Dis 1994;23(4):621.

20. Jacob V, Le Carpentier JE, Salzano S, Naylor V, Wild G, Brown CB, EI Nahas AM. IGF-1 a marker of undernutrition in hemodialysis patients. Am J Clin Nutr 1990;52:39-44.

21. Vehe K, Brown RO, Moore LW, Acciardo S, Luter RW. The efficacy of nutrition support in infected patients with chronic renal failure. Pharmacotherapy 1991;11(4):303-307.

22. Sreedhara R, Avram MM, Blanco M, Batsh R, Avram MM, Mittman N. Prealbumin is the best nutritional predictor of survival in hemodialysis and peritoneal dialysis. Am J Kidney Dis 1996;28(6):937-942.

23. Laird NM, Berkey CS, Lowrie EG. Modeling success or failure on dialysis therapy. The National Cooperative Dialysis Study. Kidney Int 1983;3(Suppl 13):S101-106. 
APPENDICES 


\title{
Appendix A
}

\section{INFORMED CONSENT}

\section{SERUM TRANSTHYRETIN (PREALBUMIN) IN HEMODIALYSIS PATIENTS: RELATIONSHIP TO NUTRITIONAL STATUS AND PROTEIN CATABOLIC RATE}

\begin{abstract}
YOU ARE ASKED TO READ THE FOLLOWING FORM TO MAKE SURE THAT YOU COMPLETELY UNDERSTAND WHAT WILL HAPPEN IF YOU AGREE TO TAKE PART IN THIS RESEARCH STUDY. SIGNING THIS FORM MEANS THAT THE STUDY HAS BEEN EXPLAINED TO YOU AND THAT YOU GIVE YOUR PERMISSION TO TAKE PART. THE FEDERAL GOVERNMENT REQUIRES YOUR APPROVAL IN WRITING BEFORE YOU TAKE PART IN ANY RESEARCH STUDY. IT IS IMPORTANT THAT YOU KNOW WHAT WILL TAKE PLACE AND WHAT RISKS ARE INVOLVED BEFORE YOU DECIDE WHETHER OR NOT TO TAKE PART IN THIS STUDY.
\end{abstract}

\section{RESEARCH PURPOSE AND DURATION}

The research project entitled "Serum transthyretin (prealbumin) in hemodialysis patients: relationship to nutritional status and protein catabolic rate" is to be conducted by Annmarie Duggan R.D., L.D. and Fatma G. Huffman Ph.D., R.D. as Principal Investigators from Florida International University. This research will last approximately 3 months starting Summer 1996 and there will be approximately 70 participants in the total sample.

The purpose of this research is to determine if serum transthyretin is an early marker of adequacy of nutritional status and if there is a correlation between low levels of this protein and a low protein catabolic rate.

\section{PROCEDURES}

You will continue to have your usual monthly lab work drawn. Your albumin, transthyretin, cholesterol and blood urea nitrogen levels will be recorded as study data. For three consecutive months you will also have a pre dialysis blood urea nitrogen and a transthyretin level drawn on the Friday after your monthly bloodwork. During the entire three month study period, only 10 milliliters of additional blood will be drawn. You will be asked to collect a 24 hour urine specimen if you urinate more than $240 \mathrm{cc}$ ( 8 ounces) per day.

\section{RISKS OR DISCOMFORTS}

There are no known risks or discomforts involved in your participation in this research study.

\section{BENEFITS TO YOU}

Although it may not be a directly benefit you to participate, this study will contribute knowledge about adequate nutritional assessment for hemodialysis patients and could result in the early identification for your need for nutrition intervention. You will continue to receive your routine monthly nutrition counseling as usual. 


\section{COST TO YOU FOR TAKING PART IN RESEARCH STUDY}

There will be no cost to you for taking part in this study.

\section{PAYMENT FOR TAKING PART IN RESEARCH STUDY}

You will not be paid for taking part in this research study.

\section{CONFIDENTIALITY}

All information which refers to, or can be identified with you, will remain confidential to the extent permitted by law. No information will be revealed about you or your part in this study, without your permission or the permission of your legally authorized representative, except that which may be necessary for the Research Committee to satisfy their legal responsibility for review of the project.

\section{COMPENSATION FOR RESEARCH RELATED INJURY}

Financial compensation for research-related injury of loss of wages is not available; however, necessary emergency medical care will be provided without cost, if not covered by a third party payer.

\section{WHOM TO CONTACT FOR ANSWERS}

If you desire further information about this research contact Fatma Huffman Ph.D. at 305-348-2878 at Florida International University or Annmarie Duggan. R.D. at 954-345-2446.

\section{PARTICIPATION IS VOLUNTARY}

Your participation in this study is voluntary. If you wish, you may choose not to take part in this study. You may withdraw your consent and discontinue participation in this research project at any time without any negative consequences.

\section{I HAVE READ, UNDERSTOOD, AND RECEIVED A COPY OF THIS INFORMED CONSENT FORM AND AGREE TO PARTICIPATE IN THIS STUDY.}

Principal Investigator , Date

Telephone No.
Participant
Date 


\section{PERMISO DE APROVACION}

LE HEMOS PEDIDO QUE LEA EL SIGUIENTE FORMULARIO PARA ASEGURARNOS DE QUE UTSTED ENTIENDA CONPLETAMENTE LO QUE VA A OCCURIR SI USTED ACEPTA PARTICIPAR EN ESTE ESTUDIO DE INVESTIGACIONES. AL FIRMIAR ESTE DOCUMENTO, NOS INDICA QUE A USTED SE LE HA ESPLICADO EL MOTIVA DE LA INVESTIGACION Y QUE USTED NOS HA DADO EL PERMISO PARA SU PARTICIPACION. EL GOBIEVNO FEDERAL REQUIERE QUE USTED NOS DE SU APROVACION POR ESCRITO ANTES DE QUE USTED PUEDA PARTICIPAR EN EL PROGRAMA. ES IMPORTANTE QUE USTED SEPA LO QUE VA OCCURIR Y TODOS LOS RIESGOS QUE VAN ENVOLUCRADOS ANTES DE QUE USTED DECIDA SI VA A PARTICIPAR O NO EN ESTE ESTUDIO.

\section{OBJETIVO DEL ESTUDIO Y DURACION}

El estudio titulado "Suero transthyretina en pacientos de dialisis- relacionado con pa nutricion y el indice de catabolismo de proteina" sera conducido por Annmarie Duggan R.D., L.D. y Fatma G. Huffman Ph.D., R.D. como principiantes investigadoras de la Universidad Internacional de la Florida. Este estudio durara aproximadamente tres meses comensando en 1996 y habran aproximadamente 70 participantes en el estudio. El objetivo de este estudio es para determinar si transthyretina es un indicador prematuro de una alimentacion adecuada y si hay una correlacion el estatus nutricional entr niveles vajos de esta proteina y el indice catabolismo de proteina.

\section{PROCEDIMIENTOS}

A usted le van hacer sus trabajos de laboratorio mensualmente como siempre. Su albumina, transthyretina, colesterol y urea sanguinea seran anotados como datos del estudio. Por 3 meses consecutivos, le tomarar, su nivel de urea sanguinea para calcular el indice de (un indicador de su proteina ingerida). Sera requerido que usted obetnga de órina cada $24 \mathrm{hrs}$. En el caso de que pueda orinar mas de 8 onza al dia.

\section{RIESGOSEINCOMODIDADES}

No hay riesgos conocidos ni incomodidades envolucrados con su participacion en esta investigacion.

\section{BENEFICIOS PARA USTED}

Aunque su participacion no lo beneficie directamente, esta investigacion sera muy constructiva para poder determinar una mejor evaluacion alimenticia y al mismo tiempo podremos identificar si usted necisita alteraciones en su dieta. Usted tendra sus spsiones consultorias con la dietista mensualmente como se acostumbra.

Iniciales del paciente 


\section{COSTO PARA PARTICIPAR EN EL ESTUDIO}

No habra costo alguno por su participacion en este estudio. Su copaboracion en este projecto, tendra un valor muy importante par la el futuro de todos los pacientes que se encuentrar en dialisis.

\section{RECOMPENSA POR PARTICIPACION EN ESTE ESTUDIO}

No habra recompensa monetaria por su participacion en el estudio.

\section{CONFIDENCIALIDAD}

Toda la informacion que se refiera a usted o que puedo ser identificada con usted semantendra confidencial segun permeitne las leyes de la fha. Ninguna informacion sobre usted o sobre su paricipacion sera revelada sin su permiso o el permiso de su abogado solamente sera la dibulgada informacion que sera utilizada por el comite de Investigacion. Toda la informacion sera utilizada dentro de totos los ambitos legales que pemite la ley.

\section{A QUIEN CONTACTAR PARA RESPUESTAS}

Si usted deasea mas informacion sobre este estudio investigatiorie comaniquese con Fatma G. Huffman Ph.D. al 305-348-2878 o Annmarie Duggan R.D. al 954345-2446.

\section{PARTICIPACION ES VOLUNTARIA}

Su participacion en este estudio es voluntaria. Si usted desea, puede decidir no participar en este estudio usted puede anular su permiso de aprovacion y descontinuar su participacion en este projecto a cualquier hora sin alguna consecuencia negativa sobre su tratamiento rutinario de dahisic.

10. YO HE LEIDO, ENTENDIDO, Y RECIBIDO UNA COPIA DE ESTE FORMULARIO DE APROVACION Y ESTOY DE ACUERDO A PARTICIPAR EN ESTE ESTUDIO.

Investigador Principal

No. de Telefono
Fecha

Testigo
Participante

Fecha 
ORINA JUNTE

Comionzo a juntar orina $\boldsymbol{\theta} \mathbf{n}$

Deje de juntar orina on

1. No Junto primar orina

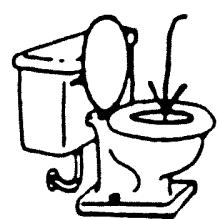

2. Esoriba hora y focha
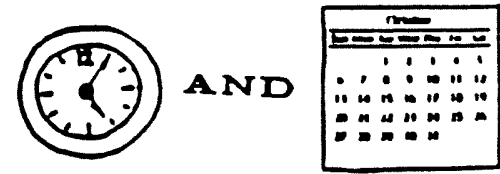

3.

Junto

toda 10 orina

hasta que venga a dialysis

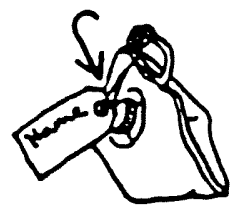

4.

Guardar orina refrigeradoro hi $\theta 10$

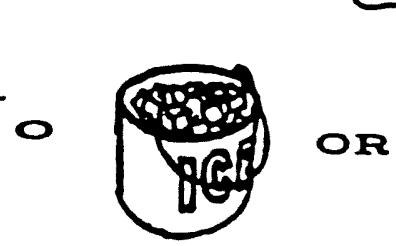

5.

Orinar

ante dialysis, junto on la bola

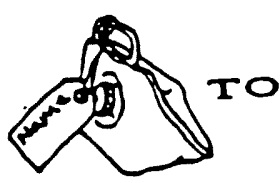

6. Escriba hora y focha

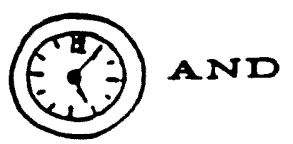

7 . Traer orina dialy y 1 y
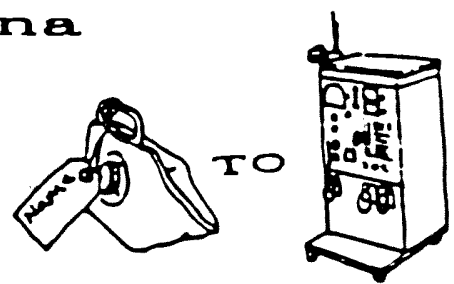

Developed by Lnda MCCann. RD, with illusirations by Brenda Ellis. PCT. Satellite Dialysis Center. Menlo Park, CA 94025

This Patient information form may be pholocopied for the purpose of distribution to patients only. but not for any other purpose. such as copying for general distribution. tor adventising or promorional purposes. lor creating new collective works, or lor resale. 
INSTRUCTIONS FOR URINE COLLECTION

Start saving urine on

Stop saving urine on

STEPS

1. DO NOT SAVE i irst

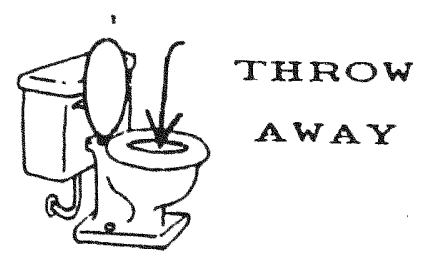

2. Write down time and date or
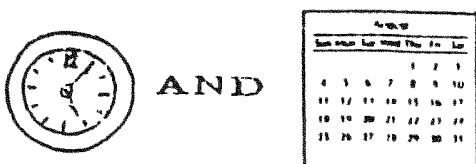

3. Save all urine in bag unt i l you come back ror dialysis.

4. keep urine beg

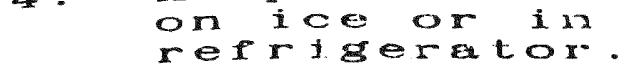

refriserator.
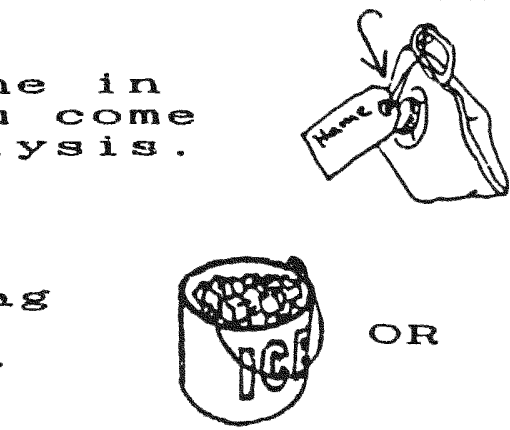

5. Urimale berore coming to dialysis and save in urine bag.

6. Write downtime and date or last urine smod.
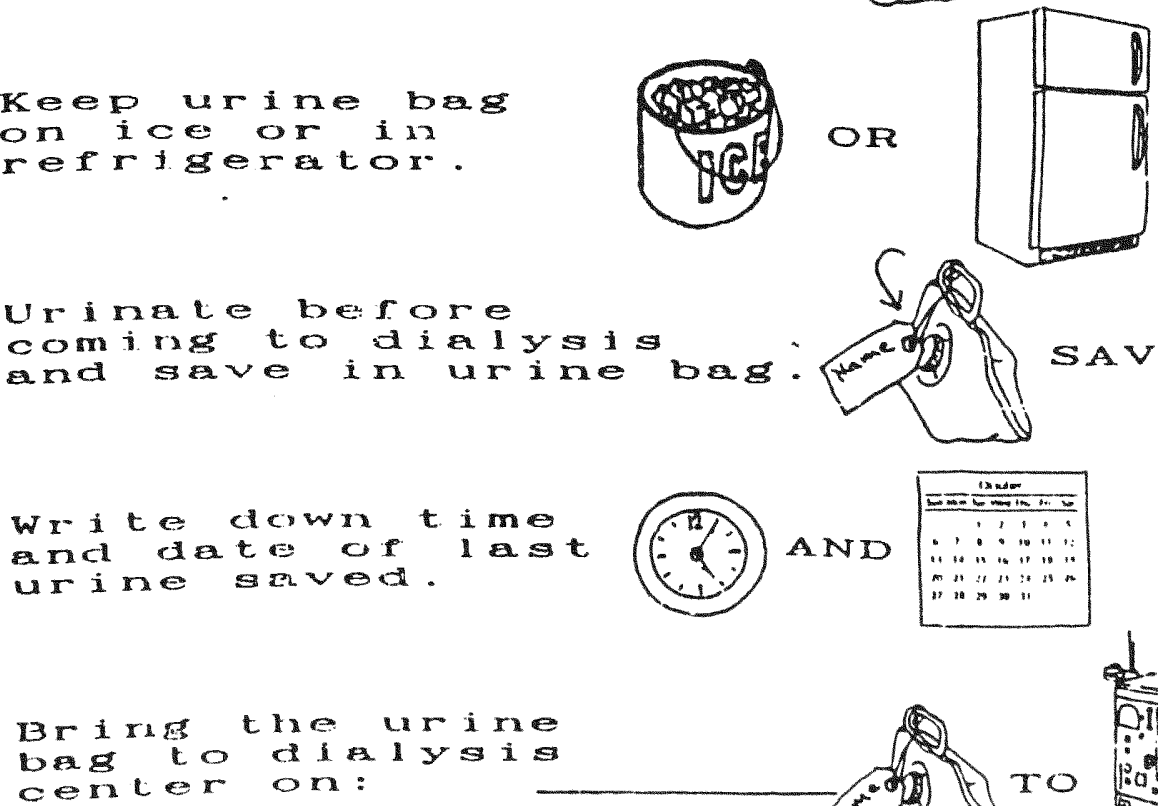

7. brirge the urine center on:

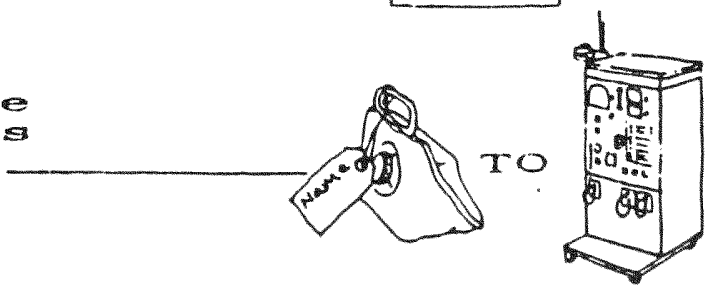

